\title{
Edukacyjna rola ilustracji w dziewiętnastowiecznej prasie dla dzieci i młodzieży
}

Grafika ilustracyjna w Europie swój złoty okres osiągnęła w XIX w. Stulecie to, będące świadkiem wielkiego rozwoju przemysłu i techniki, również w zakresie technik graficznych uzyskało spore zasługi. Grafika, szczególnie popularna w czasach nowożytnych, w wieku XIX zaczęła zmieniać swój status. Dzięki licznym unowocześnieniom przestała służyć tworzeniu tylko i wyłącznie autonomicznego dzieła sztuki, przeznaczonego na ogół dla wybranych grup społecznych. Jej wytwór, czyli rycina, powielana w dużej liczbie egzemplarzy, miała się stać gałęzią sztuki mogącą dotrzeć do coraz szerszych kręgów odbiorców. Poszczególne ryciny, kolekcjonowane dotąd jedynie przez elitę i zamożne warstwy intelektualne, mogły odtąd służyć powielaniu na szeroką skalę obrazów ukazujących rozmaite aspekty rzeczywistości i docierać do przeciętnego adresata. Zaczęły pełnić funkcje nie tylko estetyczne, lecz także utylitarne, stanowiąc dopełnienie określonego tekstu.

Niniejszy artykuł ma na celu zaprezentowanie ciekawego zagadnienia, jakim jest niezwykle istotna rola ilustracji w dziewiętnastowiecznej prasie, m.in. tej przeznaczonej dla młodego czytelnika. Jak wiadomo, grafika ilustracyjna miała niebywałe znaczenie w epoce pozbawionej współczesnych środków wizualnego przekazu. Podobnie jak dzisiejsza fotografia, odgrywała rolę ważnego nośnika informacji dotyczącej obrazowania przeszłych oraz aktualnych wydarzeń, miejsc i zjawisk. Stanowiła zatem ważne medium służące edukacji społeczeństwa. Obrazując treść publikowanych tekstów, służyła pełniejszemu poznaniu poruszanych zagadnień. Zjawisko to będzie miało szczególne znaczenie dla wydawnictw przeznaczonych dla dzieci i młodzieży. Wiele ówczesnych czasopism, przeznaczonych dla tej grupy odbiorców, począwszy od drugiej połowy wieku zawierało takie ilustracje. Wskazane zagadnienia zostały oparte na analizie szaty graficznej wybranych wydawnictw tego typu.

* Mgr, doktorantka, Instytut Historii Sztuki, Wydział Historyczny, Uniwersytet Jagielloński, ul. Grodzka 53, 31-001 Kraków. 
Początek niebywałej popularności, jaką zdobyła w XIX w. grafika ilustracyjna, wiąże się z charakterystycznym dla omawianego stulecia rozkwitem wydawnictw czasopiśmienniczych. Postęp techniczny oraz rozwój nauki, która stawała się coraz bardziej powszechna, przyczyniły się do zwiększenia roli czasopism, służących jako źródło informacji, wpływających na kształtowanie opinii publicznej. Rosnące tempo życia wymagało wzrostu produkcji i przyspieszenia procesu wydawniczego, który zatracił znamiona rzemiosła, wyzbył się cech indywidualnych na rzecz masowości'.

Wiek XIX to rozkwit książki ilustrowanej, jednak tym najpowszechniejszym (bo najtańszym) sposobem dotarcia do mas okazały się czasopisma bieżące. Zaczęły powstawać tzw. czasopisma ilustrowane, dotyczące codziennych wydarzeń: problemów społecznych, polityki, ale i takich zagadnień, jak moda, szeroko pojęta kultura czy nauka. Zainicjowano ponadto wydawanie magazynów profilowanych, przeznaczonych dla określonych grup odbiorców.

Również w Polsce, z niewielkim opóźnieniem w stosunku do Europy, na szeroką skalę rozwinął się ruch wydawnictw prasy ilustrowanej - mimo niekorzystnej sytuacji podzielonych przez zaborców ziem ojczystych. Jego początki można umiejscawiać na przełomie wieków XVIII i XIX oraz w pierwszej połowie wieku XIX. Jednak to dopiero druga jego połowa stała się czasem rozkwitu utylitarnej grafiki ilustracyjnej, która powstała w Polsce równolegle do tendencji ogólnoeuropejskich. Dodatkowo zyskała charakter medium służącego walce o zachowanie polskości i promowaniu zagadnień patriotycznych, narodowych.

Przełom XVIII i XIX stulecia to okres bardzo powolnych przeobrażeń w dziedzinie grafiki ilustracyjnej w Polsce. Największym problemem było wprowadzenie ilustracji do tekstu w książce lub czasopiśmie. Najczęściej używanymi technikami graficznymi były miedzioryt i akwaforta. Jednak wykonanie tego rodzaju rycin wymagało wykwalifikowanych drukarzy, specjalistycznych pras i właściwego papieru, a także łączenia $z$ tekstem rycin odbitych na osobnych kartach. Dlatego wydanie książki czy czasopisma ilustrowanego, wykorzystującego obydwie techniki, było przedsięwzięciem niezwykle kosztownym i w warunkach polskich bardzo trudnym. Na przełomie wieków czasopisma polskie niewielkiego formatu, nieprzekraczającego rozmiarów książki, nie miały żadnych ilustracji, jeżeli zaś w wyjątkowych przypadkach dodawano do tekstu pojedyncze ryciny, to wklejano je między strony $z$ tekstem na osobnych kartach. Początkowo stosowano miedzioryty, z czasem zastąpiły je litografie ${ }^{2}$. W XIX w., wraz z dążeniem do rozpowszechnienia i swoistego skomercjalizowania ilustracji jako środka wizualnego przekazu, pojawiła się potrzeba tańszego i szybszego powielania obrazów. W tym celu zaczęto poszukiwać nowych rozwiązań w zakresie technik graficznych. Zdaniem Janiny Wiercińskiej, był to początek niespotykanej dotąd „zażyłości” i powiązania tekstu z obrazem, zaczynającym wnikać w przestrzeń słowa ${ }^{3}$. Obok wynalezionego przez Aloisa Senefeldera druku płaskiego (1818), czyli litografii,

\footnotetext{
${ }^{1}$ C. O ż a r z e w s k i, Zarys dziejów książki i księgarstwa, Poznań 1961, s. 113-114.

2 A. B a n a c h, O ilustracji, Kraków 1950, s. 102.

3 J. W i e r c iń s k a, Sztuka i książka, Warszawa 1986, s. 33-34.
} 
zdecydowanie największe znaczenie dla rozwoju ilustracji czasopiśmienniczej w drugiej połowie stulecia miało właśnie odrodzenie drzeworytu. Technika ta, starsza od sztuki drukarskiej, swój rozkwit osiągnęła w XVI w., by na początku XVII oddać prym miedziorytowi. Drzeworyt nie zaniknął, trwał na marginesie sztuki jeszcze do początku wieku XIX w formie na poły ludowych obrazków dewocyjnych. Faktem przełomowym, który spowodował jego odrodzenie było powstanie drzeworytu sztorcowego. Pod koniec XVIII w. jeden z ilustratorów angielskich Thomas Bewek - zastosował do wycinania drzeworytu lepsze narzędzia i materiały (twardy, wytrzymały na ścieranie bukszpan cięty w poprzek), dzięki czemu grafika ta, usunięta w cień przez wieki, na nowo zaczęła wzbudzać powszechne zainteresowanie. Nowoczesny drzeworyt (nazywany reprodukcyjnym) dostał się do Polski z Anglii przez Francję i szybko się przyjął jako technika odtwarzająca i sprawozdawcza, idealna do zastosowania w czasopiśmiennictwie ${ }^{4}$.

Widoczny już w pierwszej połowie XIX stulecia wzrost ilościowy czasopiśmiennictwa spowodował coraz szerszą jego specjalizację. Tendencja ta była wynikiem różnicowania się struktury społecznej kraju. Skutkiem tego zaczęło powstawać coraz więcej czasopism przeznaczonych dla określonych grup społecznych, m.in. wyodrębniło się wyraźnie czasopiśmiennictwo dla dzieci i młodzieży. Już od lat trzydziestych (1835-1836) wychodził „Magazyn dla Dzieci” jako ilustrowany dodatek do "Magazynu Powszechnego", a następnie „Magazynu Mód”. W latach pięćdziesiątych natomiast wydawano „Rozmaitości Obrazkowo-Opisowe dla Dzieci" (1853-1857). Jeżeli chodzi o czasopisma dla młodzieży, to od 1843 r. ukazywał się „Motyl”, w latach 1843-1844 nieregularnie wydawano „Zorzę", a między 1856 i 1857 „Zabawy Przyjemne i Pożyteczne” (dwa ostatnie tytuły w Warszawie) $)^{5}$. Od roku 1861 po 1866 publikowano we Lwowie cieszące się ogromną popularnością pismo „Przyjaciel Dzieci”, poświęcone nauce i zabawie, redagowane początkowo przez Amelię z Zimmermanów Zawadzką, a następnie przez Stanisława Nowińskiego. Na jego łamach drukowano artykuły dotyczące zagadnień historycznych i przyrodniczych, a także opowiadania i wiersze. W latach 1872-1874 również we Lwowie wychodził „Promyk. Ilustrowane czasopismo dla młodzieży" pod redakcją Władysława Bełzy. Zamieszczano w nim teksty historyczne i popularnonaukowe. Po upadku tego tytułu, od roku 1876, Bełza zaczął wydawać pismo o podobnym charakterze, zatytułowane „Towarzysz Pilnych Dzieci". Idee przyświecające temu wydawnictwu najlepiej obrazowały winiety tytułowe, przedstawiające małych chłopców, w skupieniu słuchających starca oraz Jezusa nauczającego dzieci. W latach 1887-1918 wydawano "Mały Światek - czasopismo dla dzieci i młodzieży ilustrowane", redagowane przez Annę Lewicką. Pismo to zawierało wszelkiego rodzaju powieści, artykuły o tematyce historycznej, popularnonaukowej, podróżniczej i moralizatorskiej. Od roku 1893

${ }^{4}$ A. B a n a c h, Polska książka ilustrowana 1800-1900, Kraków 1959, s. 216. Szerzej na temat techniki drzeworytniczej stosowanej w czasopiśmiennictwie XIX w. zob.: M. O p ałe k, Drzeworyt w czasopismach polskich XIX stulecia, Wrocław 1949.

${ }^{5}$ E. Tom aszewski, Czasopisma zaboru rosyjskiego (1832-1864), [w:] Prasa polska w latach 1661-1864, red. J. Łojek, Warszawa 1976, s. 175-177. 
(również we Lwowie) pojawił się dwutygodnik ilustrowany dla dzieci „Wiek Młody”, którego redaktorem była Zofia Mrozowicka. Artykuły o charakterze przyrodniczym i historycznym wzbogacały ilustracje Jana Styki oraz Józefa Siemiradzkiego. W 1898 r. powołano miesięcznik dla dzieci i młodzieży wiejskiej „Gwiazdka”, redagowany przez Bolesława Wysłoucha. Dla młodzieży akademickiej przeznaczone było pismo „Młodość”, założone w setną rocznicę urodzin Adama Mickiewicza. Zamieszczane tam ilustracje propagowały prace Jana Bukowskiego, Stanisława Wyspiańskiego, Jana Weissa i Xawerego Dunikowskiego ${ }^{6}$.

Wymienione tytuły świadczą o tym, że wśród rozmaitych odbiorców dziewiętnastowieczni wydawcy w końcu dostrzegli również potrzeby młodego czytelnika. Dokumentują to chociażby słowa zawarte w artykule z 1935 r., opublikowanym na łamach „Kuriera Literacko-Naukowego”, na temat Iwowskiego czasopiśmiennictwa dla dzieci i młodzieży w XIX w.:

[...] nadchodziły czasy szczególnie pomyślne dla wszystkich wydawnictw dziecinnych, odkąd przyszło wreszcie odkrycie dziecka i zrozumienie, że ma ono odmienną i różną od dorosłych psychikę, odrębny świat zainteresowania, inny sposób patrzenia na zjawiska, w ślad za czem trzeba było tworzyć nową literaturę dla dzieci, zdobyć umiejętność pisania dla nich, orjentować się w nowych potrzebach i wymogach ${ }^{7}$.

Należy podkreślić, że czasopisma przeznaczone dla dzieci i młodzieży miały zdecydowanie oświatowo-wychowawczy charakter. Podobnie jak literatura przeznaczona dla tych grup wiekowych, tak i prasa miała być podporządkowana ówczesnej teorii pedagogicznej, co wynikało przede wszystkim z edukacyjnej roli tego typu środka przekazu. Teksty miały wydźwięk moralizatorski, kładziono nacisk na ich etyczne wartości. O rozwoju czasopiśmiennictwa dla dzieci i młodzieży można mówić zwłaszcza od lat sześćdziesiątych XIX stulecia, kiedy na łamach prasy o charakterze pedagogicznym i społecznym miały miejsce szerokie dyskusje na tematy wychowawcze. Niemały wpływ na wydźwięk ideowy publikowanych artykułów wywierała ówczesna sytuacja polityczna kraju zniewolonego przez zaborców. Należało bowiem ze szczególnym naciskiem uczyć młode pokolenie Polaków historii ojczystej oraz kształtować postawy patriotyczne ${ }^{8}$.

Wskazane czasopisma miały propagować pewne wzorce postaw, zachowań, a także wprowadzać młodego czytelnika w świat szeroko pojętej wiedzy o świecie. Treść zawarta w tego rodzaju wydawnictwach nie miałaby tak silnego oddziaływania na młodego odbiorce, gdyby nie towarzystwo ilustracji, które obrazowały to, czego samo słowo nie mogło oddać, a więc konkretny wygląd opisywanych osób, rzeczy, zjawisk i miejsc. Oprócz wizualizacji, ilustracja pełniła również funkcje nośnika ideowych treści publikowanych tekstów, co miało szczególne znaczenie we wszelkiego rodzaju powiastkach o charakterze pouczającym i moralizatorskim.

${ }^{6}$ J. Jar owiecki, Dzieje prasy polskiej we Lwowie do 1945 r., Kraków-Wrocław 2008, s. $162-166$.

7 B. N a dolski, Lwowskie czasopiśmiennictwo dla dzieci i młodzieży w XIX w., „Kurier Literacko-Naukowy" 1935, R. 12, nr 34, s. 5.

$8 \mathrm{~J}$. J a r o w i e c k i, Dzieje prasy..., s. 162. 
Analizując rozmaite ilustrowane pisma XIX w. przeznaczone dla młodego pokolenia, można wyodrębnić szereg powtarzających się często motywów ikonograficznych. Przedstawiają one w wyrazisty sposób pewne tendencje epoki w kształtowaniu świadomości młodego pokolenia Polaków i jego edukacji. Do szczególnie popularnych tematów ilustracyjnych w omawianym typie prasy należały portrety znanych osób, zarówno ważnych postaci historycznych, jak i współczesnych. Ilustracje tego typu miały na celu zapoznawać najmłodszych z wyglądem znanych osobistości świata nauki, polityki czy sztuki. Na ogół ukazywały one osobę w półpostaci i towarzyszyły tekstom biograficznym na jej temat. Przykładem może być tu rycina zamieszczona w "Towarzyszu Pilnych Dzieci”, ukazująca popiersie króla Jana III Sobieskiego na kolumnie w Żurawnie, dopełniająca tekst: Historya polska opowiedziana Jadwini przez jej mamę. Królowie obieralni (ryc. 1) $)^{9}$. Inny tego rodzaju przykład stanowi rycina ukazująca marszałka wielkiego koronnego hetmana polskiego Jerzego Lubomirskiego, $\mathrm{z}$ buławą w lewej dłoni. llustracja towarzyszy tekstowi biograficznemu i opisowi bohaterskich czynów tego wielkiego Polaka.

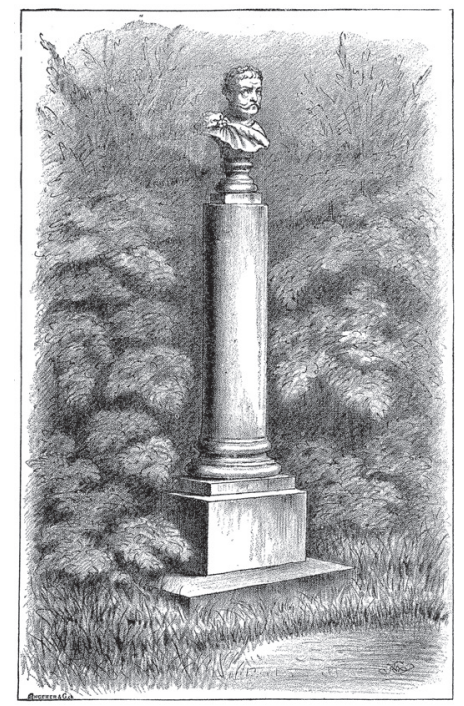

Ryc. 1. Pomnik

Jana III Sobieskiego

„Towarzysz Pilnych Dzieci” 1879 (ze zbiorów Biblioteki Jagiellońskiej)

Czasopisma ilustrowane miały zasadniczy wkład w kształtowanie świadomości i wiedzy na temat ważnych dla kultury Polski miejsc i zabytków. Tradycja zamieszczania widoków miejskich oraz budowli, głównie pałaców i kościołów, w pismach ilustrowanych wywodzi się z zapoczątkowanego jeszcze pod koniec XVIII w. przez króla Stanisława Augusta Poniatowskiego odkrywania i zachowywania w pamięci miejsc ważnych dla historii i kultury naszego kraju. Również prasa dziecięca i młodzieżowa z pobudek patriotycznych promowała tego typu widoki cennych zabytków architektury, będących symbolami chlubnej przeszłości zniewolonej ojczyzny. Zjawisko to wynikało z ogólnych tendencji epoki, nastawionej na ochronę zabytków sztuki rodzimej. Najczęściej ryciny przedstawiały kościoły, rezydencje magnackie, ważne budynki użyteczności publicznej, a w szczególności ruiny zamków. llustracje te wzbogacały teksty o charakterze poznawczym, opisujące dany zabytek i przytaczające towarzyszącą mu historią lub legendą. Do przykładów tego typu należy ilustracja przedstawiająca ruiny zamku Tenczyńskiego pod Krakowem. Ukazuje ona pozostałości czternastowiecznej posiadłości kasztelana krakowskiego Nawoja (potomka prastarej rodziny Toporczyków),

9 Zob. ryc. Historya polska opowiedziana Jadwini przez jej mamę. Królowie obieralni, „Towarzysz Pilnych Dzieci" 1879, R. 4, nr 5, s. 37. 
będącej następnie własnością słynnego rodu Tenczyńskich, na tle krajobrazu wzbogaconego sztafażem. Rycina prezentuje dziewiętnastowieczny stan zachowania tej budowli, zniszczonej przez wojska szwedzkie. Autor artykułu tak opisuje jej wygląd:

Dzisiaj nie obaczysz ani wież, ani ogrodu, ale ruiny jakby w skały wrośnięte. Jak o każdym tak i o tym zamku krąży między ludem podanie jakby gdzieś w podziemnych pieczarach zamkowych wielkie przechowywały się skarby"10.

Inna ilustracja ukazująca ruiny niegdyś okazałych budowli ojczystych to $R u$ iny zamku w Dobromilu (ryc. 2). Została zamieszczona na łamach „Przyjaciela Dzieci”, w obrębie opowiadania, w którym ojciec pokazuje synkowi pozostałości chlubnej przeszłości zniewolonej ojczyzny. Aby wzbudzić w młodym czytelniku uczucia patriotyczne, w tekście zawarto następujące słowa:

Mały chłopczyna uczuł dziwną boleść i smutek w swem sercu. Wszakżeż patrzał na stare ślady sławy i potęgi swej ojczyzny... A któż z was, moi czytelnicy, nie kocha tej pięknej, drogiej naszej ojczyzny?...11

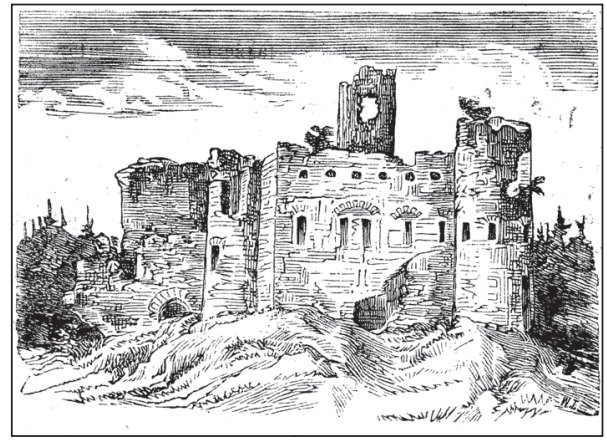

Ryc. 2. Ruiny zamku w Dobromilu „Przyjaciel Dzieci” 1863

(ze zbiorów Biblioteki Jagiellońskiej)

Popularne były również widoki polskich budowli sakralnych, wraz z opisami, które szerzyły nie tylko wiedzę stricte historyczną na temat dziejów danego obiektu, ale i wprowadzały terminologię zaczerpniętą z rodzącej się naukowej historii sztuki. Określenia stylów historycznych, w tym gotyku zawarte zostało $w$ artykule, któremu towarzyszyła rycina $z$ przedstawieniem powszechnie znanej katedry św. Jana w Warszawie ${ }^{12}$ (ryc. 3). Ilustracje prasowe epoki przedstawiały również sceny o charakterze historycznym, związane z odległą przeszłością kraju. Towarzyszyły tekstom o często patetycznym wydźwięku, mającym wzbudzić w dziecku lub dorastającym młodym człowieku umiłowanie do poznawania i kultywowania historii Polski. Na ogół były to znane epizody z czasów panowania najbardziej znanych królów polskich, nierzadko wzbogacone o wątki legendarne. Przykładem tego rodzaju jest chociażby rycina opublikowana w „Przyjacielu Dzieci”, ukazująca św. Kingę, wrzucającą swój pierścień do szybu solnego, która znajduje się w tekście na temat zasług królowej:

Wiecie dzieci kochane, jak wielu dzielnych i potężnych mieliśmy królów, co narodem polskim chlubnie rządzili, kraj swój zasłaniali i bronili od nieprzyjaciół, wspierali nauki i rzemiosła i w każdym

10 Józef z Bochni, Tenczyński zamek, „Przyjaciel Dzieci” 1864, R. 3, nr 18, s. 281-282; zob. również ryc., tamże, s. 281.

11 Pielgrzymka, „Przyjaciel Dzieci” 1863, R. 3, nr 18, s. 283; zob. również ryc., tamże., s. 281.

12 Zob. ryc. Katedra św. Jana w Warszawie, „Świat” 1879, R. 4, nr 15, s. 169. 


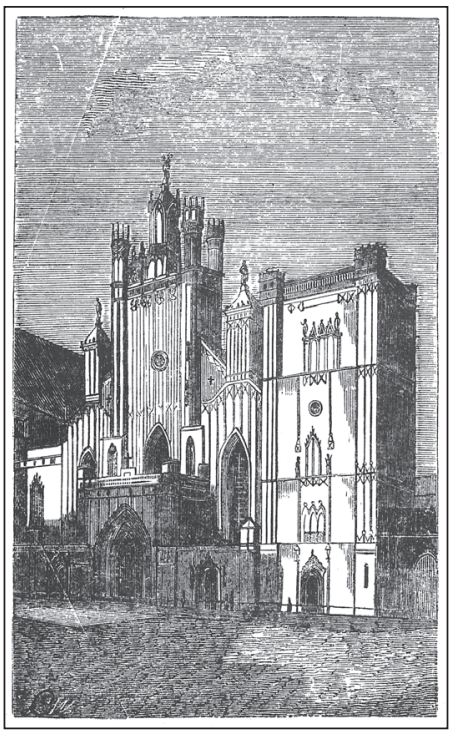

Ryc. 3. Katedra św. Jana w Warszawie

„Świat” 1879

(ze zbiorów Biblioteki Jagiellońskiej) względzie dbali o szczęście poddanych [...]. Pomiędzy niemi jedno z pierwszych miejsc zajmuje św. Kinga, Bolesława Wstydliwego żona, a córka Beli, króla Węgierskiego. Ona to, wzór najwznioślejszej cnoty i najczystszej pobożności $[\ldots]^{13}$.

Popularne były także sceny ze znanych bitew, w które obfitowały dzieje Polski. Świadczy o tym rycina ukazująca scenę obrony Jasnej Góry przez księdza Koredckiego. (ryc. 4), towarzysząca tekstowi:

Ksiądz Kordecki pokładając nadzieję w Opatrzności Bożej, [...] podczas gdy Szwedzi, oburzeni jego stałością, zaczęli gotować się do szturmu, on przy odgłosie dzwonów odprawiał uroczystą procesję po wałach fortecznych ${ }^{14}$.

Szczególną popularnością w prasie dziecięcej i młodzieżowej cieszyły się artykuły popularnonaukowe, zwłaszcza opisujące rozmaite gatunki fauny i flory. Niezwykle szczegółowe ryciny towarzyszyły tekstom na temat rozmaitych zwierząt, zwłaszcza tych egzotycznych.

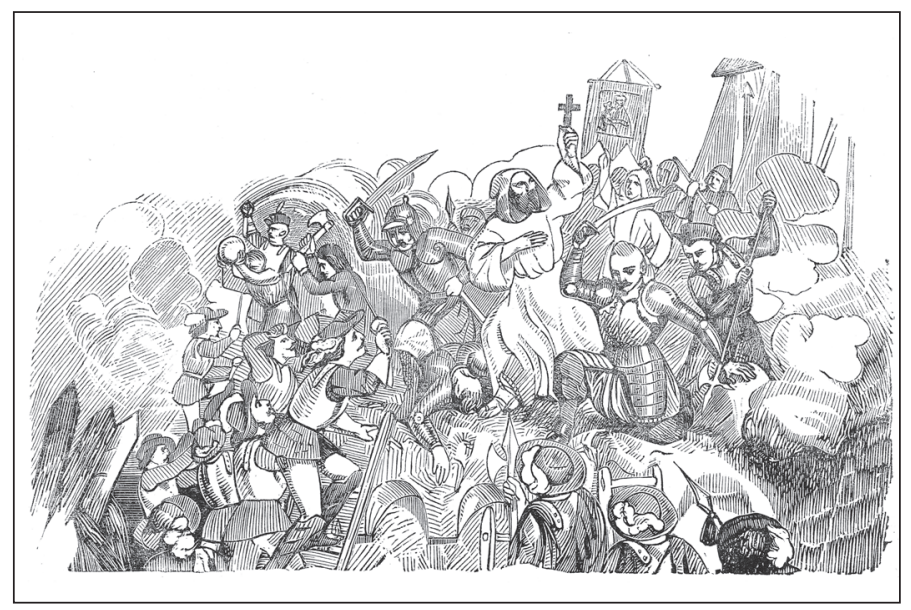

Ryc. 4. Ksiądz Kordecki broni Jasnej Góry

„Przyjaciel Dzieci” 1864

(ze zbiorów Biblioteki Jagiellońskiej)

Najczęściej publikowano ilustracje ukazujące autonomiczne wizerunki zwierząt, wraz ze szczegółowymi opisami ich wyglądu oraz zwyczajów. Przykładem

13 Święta Kinga, „Przyjaciel Dzieci”1866, R. 4, nr 1, s. 7; zob. również ryc., tamże, s. 9.

14 Obrona Częstochowy, „Przyjaciel Dzieci” 1864, R. 3, nr 13, s. 202; zob. również ryc., tamże, s. 201. 
może być rycina ukazująca rajskiego ptaka, zwanego też latawcem, obrazująca bujność jego upierzenia ${ }^{15}$ lub portret wspaniałego tukana (ryc. 5):

Tukan jest nazwą ptaka ubarwionego, przebywającego głównie w Brazylii. Najwięcej zwraca uwagę jego ogromny dziób, większy niż cała pozostała część głowy ${ }^{16}$.

Zamieszczano również ilustracje obrazujące epizody i zjawiska związane ze światem przyrody. Przykładem może być rycina przedstawiająca połów wielorybów, odbywający się w następujący sposób:

Dwóch ludzi wsiada do jednej z sześciu lub siedmiu szalup [...], i olbrzymie dzidy przywiązane do sznurów i kilkaset stóp długości mających, wbijają się w grzbiet wieloryba [... $]^{17}$.

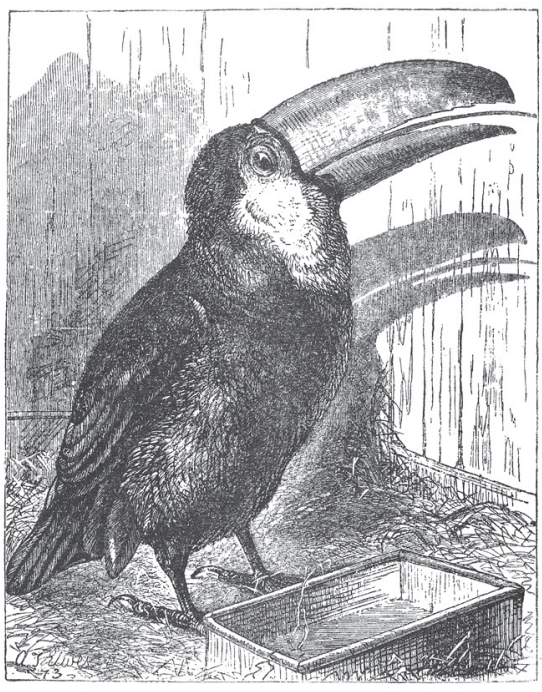

Ryc. 5. Tukan, „Świat” 1879 (ze zbiorów Biblioteki Jagiellońskiej)

Bardzo charakterystyczną cechą dziewiętnastowiecznej prasy dziecięcej i młodzieżowej były historie, opowiadania czy powieści o wymiarze umoralniającym. Również tego typu teksty wzbogacone były ilustracjami, wyraźnie wzmacniającymi przekazywane treści i odczucia. Krótkiemu opowiadaniu, opublikowanemu w „Przyjacielu Dzieci” pt. Wdzięczność Wojtusia, towarzyszy rycina (ryc. 6) ukazująca na tle krajobrazu wiejskiego małego chłopca wiszącego na gałęzi drzewa i tytułowego Wojtusia, który śpieszy mu z pomocą, niosąc drabinę. Opowiadanie kończy puenta, że wspinanie się po drzewach to "rozrywka wielce niebezpieczna i chłopcy nie powinni jej się oddawać, zwłaszcza że nie zawsze w niebezpieczeństwie znajdzie się jakiś Wojtuś z drabinką jakby na zawołanie"18.

Inny przykład to niewielka rycina przedstawiająca małego chłopca w szkolnym stroju, ze spuszczoną głową i spojrzeniem odwróconym od ojca, ze srogą miną studiującego złe wyniki na świadectwie szkolnym ${ }^{19}$.

Popularne były ponadto krótkie historyjki, składające się z kilku obrazków objaśnionych odpowiednimi podpisami, w samej formie przypominające współczesne komiksy, z umoralniającą puentą. Przykładem tego typu jest ilustracja pt. Tragedya, zamieszczona w piśmie dla dzieci i młodzieży „Świat”, złożona z czterech

\footnotetext{
15 Zob. ryc. Rajski ptak, „Towarzysz Pilnych Dzieci” 1876, R. 1, nr 1, s. 5.

16 Tukan, „Świat” 1879, R. 4, nr 1, s. 131; zob. również ryc., tamże, s. 132.

17 Połów wielorybów, „Przyjaciel Dzieci” 1866, R. 4, nr 2, s. 24; zob. też ryc., tamże, s. 25.

18 Wdzięczność Wojtusia, „Przyjaciel Dzieci” 1866, R. 4, nr 3, s. 41; zob. również ryc., tamże.,
} S. 40 .

19 Zob. ryc., „Wiek Młody” 1893, R. 1, nr 14, s. 55. 


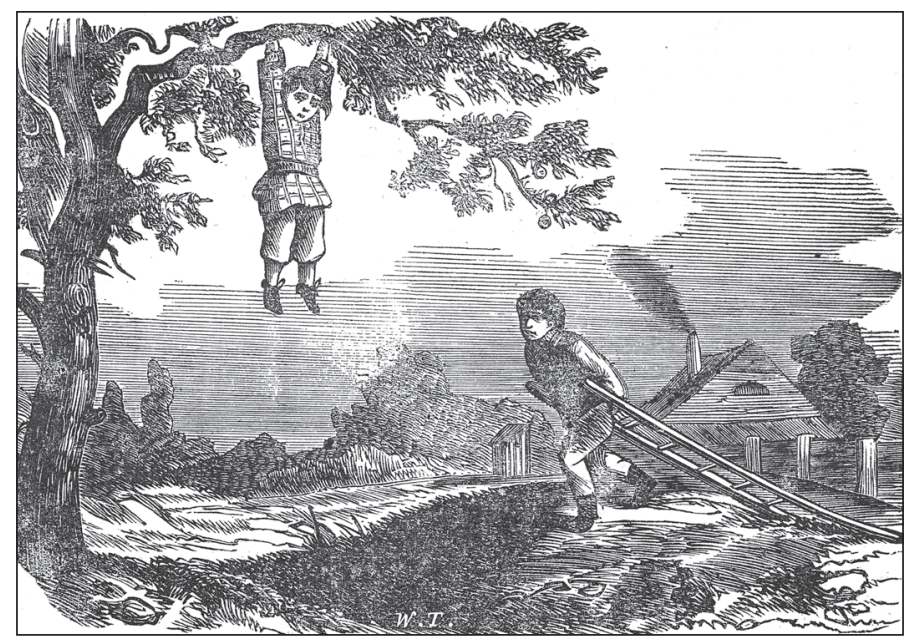

Ryc. 6. Wdzięczność Wojtusia

„Przyjaciel Dzieci” 1866 (ze zbiorów Biblioteki Jagiellońskiej)

scen obrazujących powiastkę o małej dziewczynce, która nieopatrznie wypuściła ptaszki z klatki, a te padły łupem domowego kota $^{20}$.

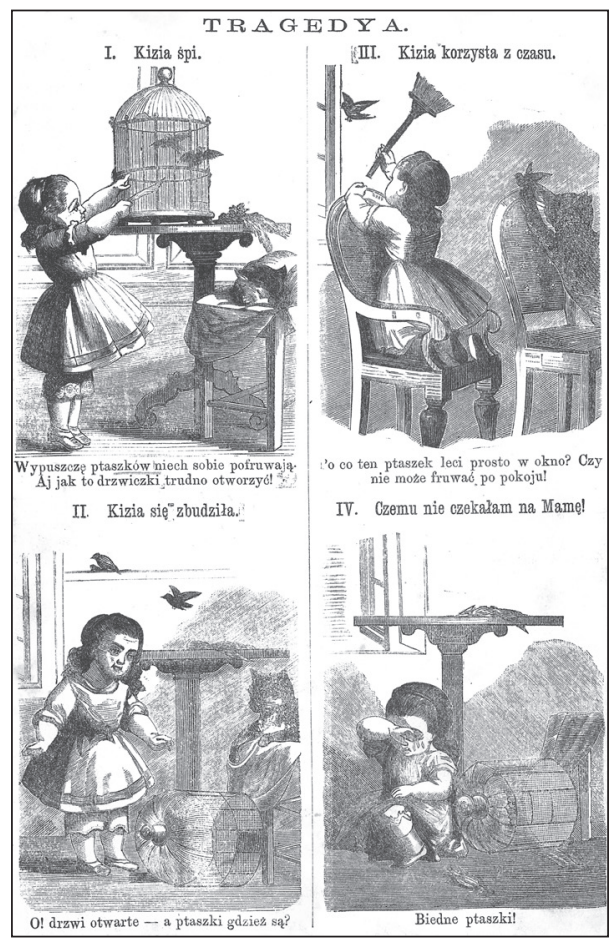

Ryc. 7. Tragedya, „Świat” 1876 (ze zbiorów Biblioteki Jagiellońskiej)

20 Zob. ryc. Tragedya, „Świat” 1876, R. 1, nr 2, s. 56. 
Wdzięcznym tworzywem dla artystów ilustrujących prasę dziecięcą były ryciny towarzyszące wierszykom dla najmłodszych. W większości przypadków utwory takie mogły mieć charakter humorystyczny lub moralizatorski, np. wskazywały potrzebę otwarcia się na bliźniego w potrzebie. Wiele dziewiętnastowiecznych rycin, zwłaszcza w połowie wieku, miało charakter sentymentalny, ale i realistyczno-krytyczny, tzn. ukazywało niesprawiedliwość społeczną. Takim przykładem jest ilustracja zamieszczona w piśmie dla młodego pokolenia „Wiek Młody”, przedstawiająca troje biednych, zmarzniętych dzieci, siedzących na ulicy. Rycina obrazuje wiersz pt. Biedne dzieci (ryc. 8):

O! wy w pałacach - bogatych domach...

Dzieci, co zimna, głodu nie znacie...

Czy wy też o nas, o dzieciach biednych,

Czasem myślicie i pamiętacie? [... $]^{21}$.

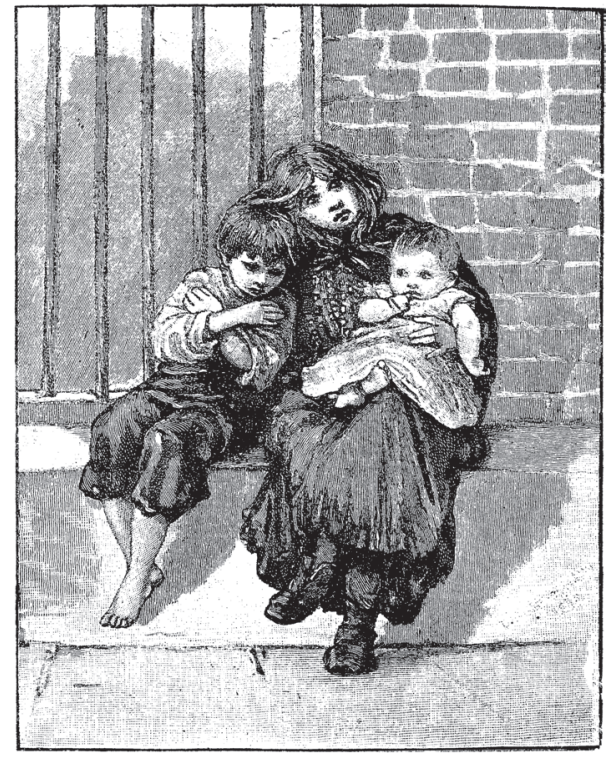

Ryc. 8. Biedne dzieci „Wiek Młody” 1895

(ze zbiorów Biblioteki Jagiellońskiej)

Patriotyczne postawy najmłodszych kształtowano również poprzez popularyzację wiedzy o bogactwie natury i kultury rozmaitych regionów własnej ojczyzny. Tendencja ta wynikała z charakterystycznego dla omawianego stulecia zamiłowania do turystyki. Modę tę ilustruje rycina wyobrażająca zakład kąpieli siarczanych w Lubieniu, niedaleko Lwowa, a tak opisują ją słowa zawarte w tekście:

[...] niekoniecznie trzeba jeździć do obcych wód - niekoniecznie należy wierzyć w zagraniczne kuracye - skoro Bóg w łonie ojczystej ziemi tyle zdrowotnych poprowadził źródeł, że tylko schylić się, czerpać z nich obficie i dziękować niebu za jego dobrodziejstwa ${ }^{22}$.

Często publikowano artykuły o charakterze na poły poznawczym, na poły etnograficznym, przybliżając młodemu czytelnikowi specyfikę regionów Polski, zawierające opisy życia miejscowej ludności. O tej tendencji świadczy chociażby rycina towarzysząca tekstowi na temat „ruskich górali”, ukazująca młodzieńca odzianego w typowy góralski strój, odpoczywającego pod drzewem. Opis tej ilustracji został zawarty w tekście artykułu:

21 Jadwiga z Z. S., Biedne dzieci, „Wiek Młody” 1896, R. 4, nr 3, s. 21; zob. również ryc., tamże, s. 21.

22 Lubień, „Towarzysz Pilnych Dzieci” 1880, R. 1880, nr 21, s. 166. Zob. również ryc., tamże, s. 165. 
Strój Góralów ruskich jest bardzo piękny i odpowiada zupełnie ich sposobowi życia. Na głowie, z której spływają w długich, zakręconych zwojach bujne i najczęściej ciemne włosy, spoczywa czarny niski kapelusz z szerokimi i w górę zawiniętymi kresami, krótka koszula z wyszywanymi w najrozmaitsze hafty naramiennikami spięta jest u góry wielką okrągłą szpinką z błyszczącego kruszcu i przepasana u dołu szerokim, skórzanym pasem $[\ldots]^{23}$.

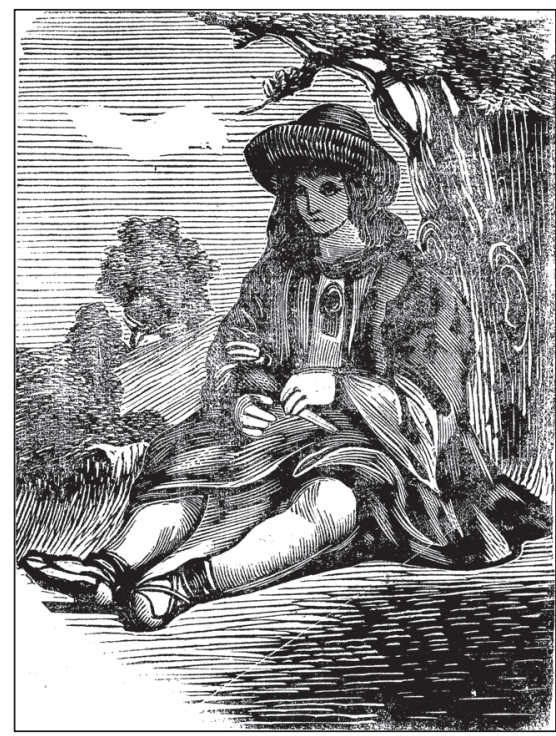

Ryc. 9. Ruski Góral

„Przyjaciel Dzieci” 1863

(ze zbiorów Biblioteki Jagiellońskiej)

Omówione motywy ikonograficzne nie wyczerpują całego zasobu tematyki ilustracji w czasopiśmiennictwie dziecięcym i młodzieżowym, pojawiały się bowiem również widoki dalekich, nierzadko egzotycznych krajów, towarzyszące relacjom z podróży, ryciny prezentujące wynalazki i zjawiska zaczerpnięte ze świata nauki i przyrody oraz szereg innych.

$\mathrm{Na}$ koniec należy wspomnieć o wartości artystycznej grafiki ilustracyjnej w czasopismach dziecięcych i młodzieżowych. W większości przypadków stała ona na niezbyt wysokim poziomie, bowiem dostarczanie wrażeń estetycznych nie było jej głównym celem. Zdecydowanie miała pełnić funkcje utylitarne, służąc uzupełnianiu i wzbogaceniu treści tekstu. Podkreślić trzeba, że pewne motywy (np. widoki architektury) były powielane na podstawie rycin zamieszczanych w prasie przeznaczonej dla dorosłych, natomiast ilustracje towarzyszące wierszykom i opowiadaniom dla najmłodszych miały zdecydowanie formę artystyczną, przeznaczoną dla dziecka. Obecność ilustracji w dziewiętnastowiecznej prasie dla dzieci i młodzieży wzbogaciła jej wymiar edukacyjny, rozpowszechniając zarazem tematy ikonograficzne, ważne ze względu na ogólną wiedzę o świecie.

${ }^{23}$ Ruscy górale, „Przyjaciel Dzieci” 1863, R. 1863, nr 20, s. 312-313; zob. również ryc., tamże, s. 312 . 